\title{
EarthArXiv post-print
}

This manuscript has been accepted for publication in the Journal of African Earth Sciences in February 2018. https://doi.org/10.1016/j.jafrearsci.2018.01.006

Small modifications have been brought to the manuscript, and are listed on the next page.

Authors encourage downloading the latest manuscript version from EarthArXiv before usage.

Authors welcome comments, feedback and discussions anytime. Please, feel free to contact the first author at r.j.g.charton@tudelft.nl 
Earth ArXiv post-print

Title

The Sidi Ifni transect across the rifted margin of Morocco (Central Atlantic): Vertical movements constrained by low-temperature thermochronology.

\section{Modifications}

- The term 'subsidence' when associated with t-T models has been changed for 'burial';

- Reference for Arantegui et al., 2019 has been added alongside Arantegui et al., in prep. (see appendix);

- Figure 1 legends have been corrected;

- Mentions of 'Low-Temperature Geochronology' have been replaced for 'LowTemperature Thermochronology';. 


\section{Authors and Affiliations}

Rémi Charton, Department of Geoscience and Engineering, Delft University of Technology, P.O. Box 5048, 2600 GA Delft, The Netherlands

Corresponding author

r.j.g.charton@tudelft.nl

Giovanni Bertotti, Department of Geoscience and Engineering, Delft University of Technology, P.O. Box 5048, 2600 GA Delft, The Netherlands

g.bertotti@tudelft.nl

Angel Arantegui, School of Earth and Environmental Sciences, The University of Manchester, M13 9PL Manchester, United Kingdom

angel.arantegui@manchester.ac.uk

Luc Bulot, UM 34 Cerege CNRS (UMR 7630) - IRD (UMR 161), Aix-Marseille Université (Centre Saint-Charles), Place Victor Hugo, 13331 Marseille cedex 03, France bulot@cerege.fr

$\&$

NARG

luc.bulot@manchester.ac.uk

All authors: NARG (North Africa Research Group), UK 


\begin{abstract}
The occurrence of km-scale exhumations during syn- and post-rift stages has been documented along Atlantic continental margins, which are also characterised by basins undergoing substantial subsidence. The relationship between the exhuming and subsiding domains is poorly understood. In this study, we reconstruct the evolution of a $50 \mathrm{~km}$ long transect across the Moroccan rifted margin from the western Anti-Atlas to the Atlantic basin offshore the city of Sidi Ifni. Low-temperature thermochronology data from the Sidi Ifni area document a ca. $8 \mathrm{~km}$ exhumation between the Permian and the Early/Middle Jurassic. The related erosion fed sediments to the subsiding Mesozoic basin to the NW. Basement rocks along the transect were subsequently buried by 1 to $2 \mathrm{~km}$ between the Late Jurassic and the Early Cretaceous. From late Early/Late Cretaceous onwards, rocks present along the transect were exhumed to their present-day position.
\end{abstract}

\title{
Keywords
}

Sidi Ifni transect, Morocco, Central Atlantic, Vertical movements

\section{Highlights}

- Post-Variscan exhumation of the Anti-Atlas ceased during the Early/Middle Jurassic.

- Exhumation resumed during the Late Cretaceous.

- A period of burial is observed during the Late Jurassic to Early Cretaceous.

- The rifted Moroccan margin records variable post-Variscan thermal history along strike. 


\section{Introduction}

The models of passive margin evolution (reviewed in Watts, 2012) have been questioned in the last decade. Recent studies have convincingly documented the occurrence of episodic km-scale exhumation and burial during the syn- and post-rift stages of rifted margin evolution (e.g., Japsen et al., 2016).

Syn-rift upward movements are common in Atlantic continental margins (e.g., Oukassou et al., 2013; Jelinek et al., 2014; Japsen et al., 2016) and have usually been attributed to rift shoulder uplift. Post-rift upward movements have been documented along the North (e.g., Japsen et al., 2006; Japsen et al., 2016), Central (e.g., Bertotti and Gouiza, 2012; Amidon et al., 2016) and South (e.g., Jelinek et al., 2014; Wildman et al., 2015) Atlantic margins. Beyond the Atlantic realm, Australian margins have experienced similar movements (e.g., Tassone et al., 2012). As several studies in Morocco have proposed (e.g., Bertotti and Gouiza, 2012), anomalous vertical movements in the exhuming domain are coeval to excessive downward movements in the subsiding domain.

Despite the well-established body of evidence supporting syn- and post-rift exhumations, we still lack a quantitative comprehension of these movements. The proposed numerical models (e.g., Yamato et al., 2013) are fairly general and still unable to provide predictions by which they can be tested against observations from natural systems. This is partly due to the fact that most of these enigmatic vertical movements are documented onshore using Low-Temperature Thermochronology (LTT), without any attempt to link them to the movements in offshore areas. These observations call for an integrated analysis of the entire system from the exhuming domain (source) to the subsiding region (sink) as a required step to fully understand the involved tectonics. 
Earth ArXiv post-print
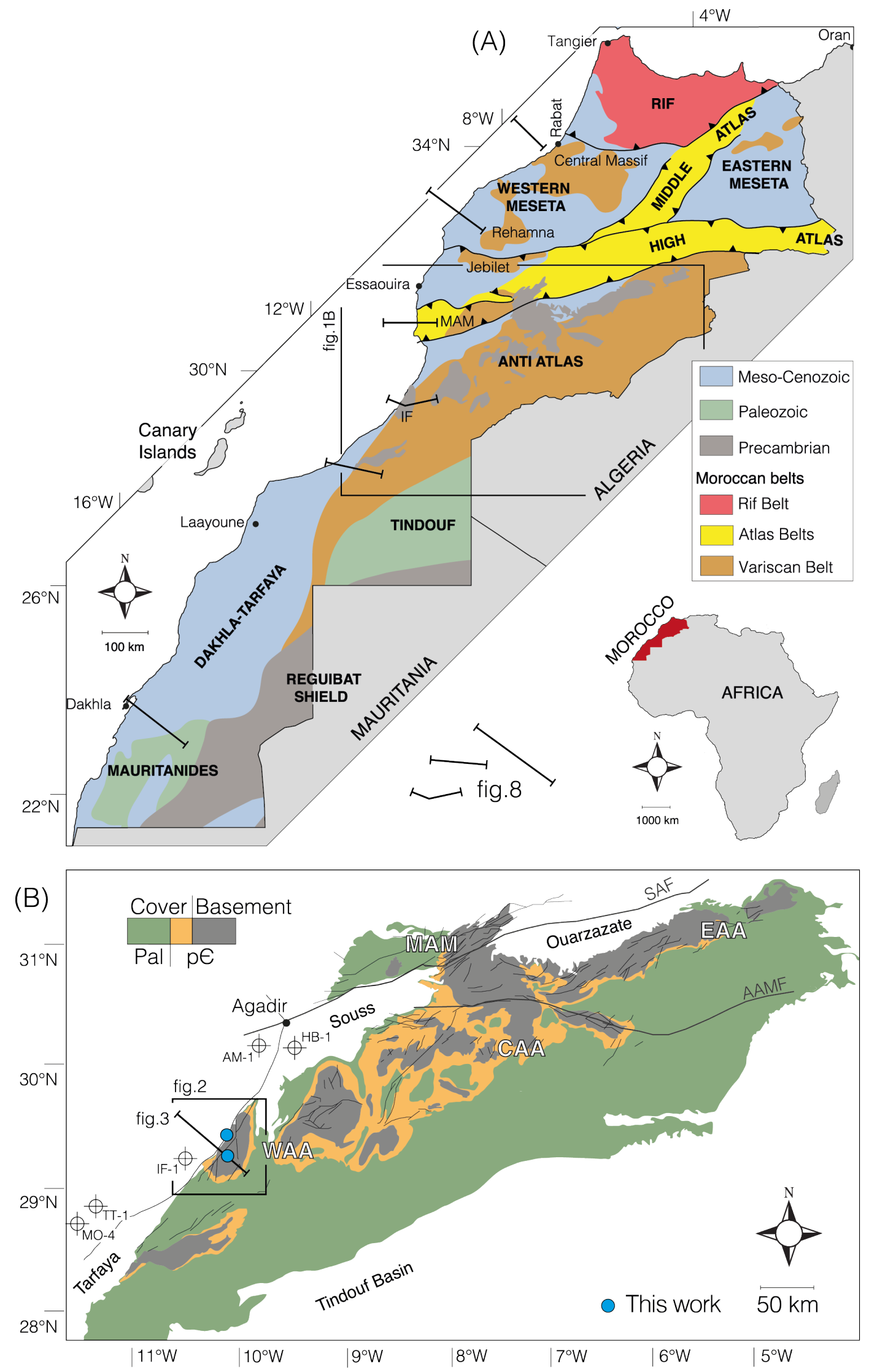

Figure 1. A) Simplified structural map of Morocco (after Hollard et al. 1985). B) Simplified geological map of the Anti-Atlas (after Hollard et al., 1985; Soulaimani et al., 2014) with sample locations. MAM: Massif Ancien de Marrakech; IF: Sidi Ifni area; WAA, CAA, and EAA: Western, Central, and Eastern Anti-Atlas, respectively; Pal: Palaeozoic; p€: Precambrian. 
In this study, we construct a $50 \mathrm{~km}$ long transect across the Moroccan rifted margin (fig. 1A) from the western Anti-Atlas to the offshore passive margin basin (fig. 1B), that we call the Sidi Ifni transect. The coexistence of Mesozoic sediments and regional unconformities in the study area makes it a key transition between the generally subsiding offshore and exhuming Anti-Atlas (e.g., Gouiza et al., 2017). Expanding the presently available lowtemperature thermochronology data base and using new and robust stratigraphic ages of the Mesozoic sediments, we present a reconstruction of syn- and post-rift vertical movements along the Sidi Ifni transect. We also compare the present-day structure and evolution of the Sidi Ifni transect to those of other segments across the Moroccan rifted margin, namely, the Rabat, Doukkala, Essaouira, North-Tarfaya and Dahkla transects. 


\section{Geological setting}

The WSW/ENE oriented Anti-Atlas (fig. 1) extends over $600 \mathrm{~km}$ with elevations reaching $3305 \mathrm{~m}$ towards its centre. The basement of the belt is composed of Neoproterozoic granites and metamorphic rocks (Pan-African orogeny; e.g., Thomas et al., 2004). The Anti-Atlas basement is partially covered by autochthonous Late Neoproterozoic and Palaeozoic sediments (e.g., Michard et al., 2008b). These rocks were deformed during the late Palaeozoic Variscan orogeny, which is characterised by a strong inversion and thickskin folding (e.g., Burkhard et al., 2006). The presently outcropping Precambrian inliers (fig. 1B) are basement folds that formed during the Variscan deformation (plis de fond; e.g., Helg et al., 2004).

The rifting of the Central Atlantic started in the Late Triassic and ended in the Early to Middle Jurassic (e.g., Michard et al., 2008a; Labails et al., 2010), and led to the separation of the Central Atlantic passive margins. The convergence between the African and European plates started in the Late Cretaceous, resulting from the South Atlantic opening (Piqué et al., 2002). In North-West Africa, the Cenozoic is marked by the Atlas orogeny. The collision between the European and African tectonic plates and related deformations that occurred in the Eocene onwards (reviewed in Frizon de Lamotte et al., 2009), are considered as mild with long wavelength crustal folding in the Anti-Atlas. 


\section{Present-day architecture of the Sidi Ifni transect}

The Sidi Ifni transect (figs. $\mathbf{2}$ and $\mathbf{3}$ ) is composed of the Sidi Ifni dome in the onshore domain and of the Atlantic continental shelf, slope, and abyssal basin in the offshore domain. The pre-Mesozoic basement outcropping onshore is affected offshore by NW and SE dipping normal faults, which bound syn-rift half grabens.

On the continental shelf, the Ifni- 1 well shows ca. $2 \mathrm{~km}$ thick Mesozoic sediments (fig. 2B), comprising the syn- and post-rift packages. The syn-rift Permian?-Triassic sediments are truncated by the Middle Jurassic sediments close to the shoreline. Westwards, Lower Jurassic platform sediments thin into basinal facies (Hafid et al, 2008), while they are truncated near the coast, and are missing in Ifni-1 well. The latter shows a Middle Jurassic section of mixed carbonates and clastics.

Mesozoic sediments in contact with Palaeozoic and Precambrian rocks are exposed along a narrow NE-SW oriented domain along the coastline (fig. 2B). Intertidal fine clastics and shallow marine carbonates, previously mapped as Lower Cretaceous or pre-Cenomanian (Hollard et al., 1985; Yazidi et al., 1986; 1991), have been re-dated using benthic foraminifera, green algae, gastropods and bivalves as Middle Jurassic (fig. 2D; Arantegui et al., 2016; see appendix). Underlying undated sediments stratigraphically conformable are fluvial clastics (figs. 2C and 2E), and will be considered in this work as Middle Jurassic. Based on field observations, their architecture shows alluvial fans downlapping on basement rocks laterally associated to alluvial plain deposits.

Offshore, undifferentiated Upper Jurassic/Lower Cretaceous neritic clastics overly the Upper Jurassic carbonate platform, and are referred to as the 'Sables de Tan-Tan' Formation (e.g.,Choubert et al., 1966; Martinis and Visintin, 1966). Finally, the Lower Cretaceous reflections in line SP-83-07 are interpreted as up-dip truncations close to the seabed in the continental shelf domain. The Cretaceous sediments drilled in Ifni-1 are neritic clastics and carbonates. The Middle Cretaceous (Aptian-Albian) to Cenozoic 
Earth ArXiv post-print

sediments are only preserved close to the shelf edge and further offshore, while the Late Cretaceous sediments are not recorded in the study areas. 


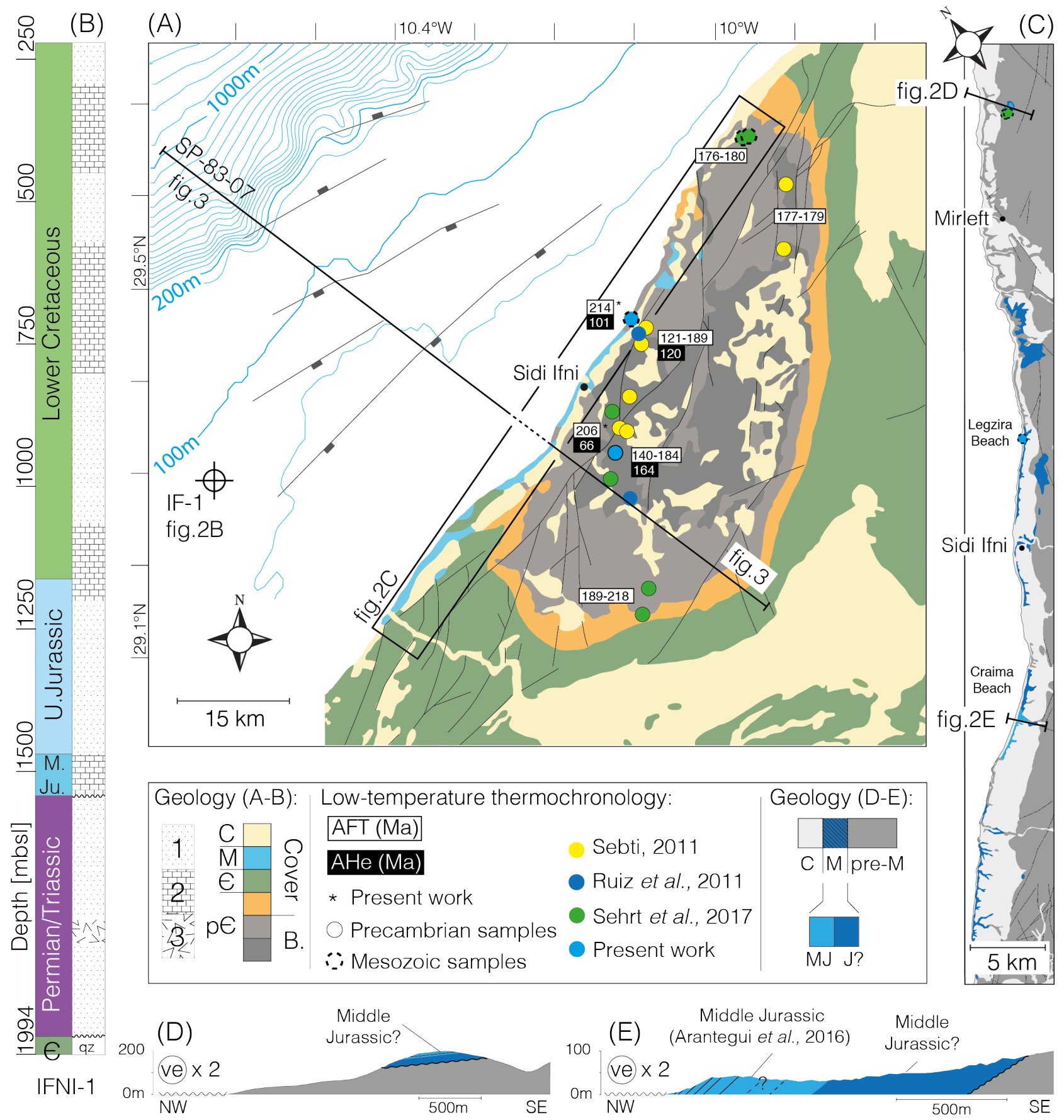

Figure 2. A) Simplified geological map of the Sidi Ifni area (after Hollard et al., 1985) and lowtemperature thermochronology data locations (Sebti, 2011; Ruiz et al., 2011; Sehrt et al., 2017; present study). Bathymetry contour lines are every $50 \mathrm{~m}$. Syn-rift offshore normal faults are from Le Roy and Piqué (2001). C: Cenozoic; M: Mesozoic; $€$ : Cambrian; $\mathrm{\epsilon}$ : Precambrian; AFT: Apatite fission track ages; AHe: (U-Th)/He dating on apatites. B) Stratigraphic log of the Ifni-1 (IF-1) well (after well report; 70 to $222 \mathrm{mbsl}$ were not examined). 1: Neritic clastics and sandstones (continental for the Triassic), 2: limestones/dolomites, 3: evaporites. C) Simplified geological map of the Sidi Ifni Margin with highlight on Mesozoic sediments (after 1/100000 geological maps of Tiznit and Sidi Ifni; Yazidi et al., 1986; 1991). J?: Middle Jurassic fluvial red conglomerates and red/pink/grey coarse to very coarse sandstones; MJ: Intertidal fine clastics and shallow marine carbonates identified as Middle Jurassic (Arantegui et al., 2016; see appendix). D-E) Crosssections illustrating the geometry of the contact between the Sidi Ifni basement rocks and the Mesozoic sediments. 


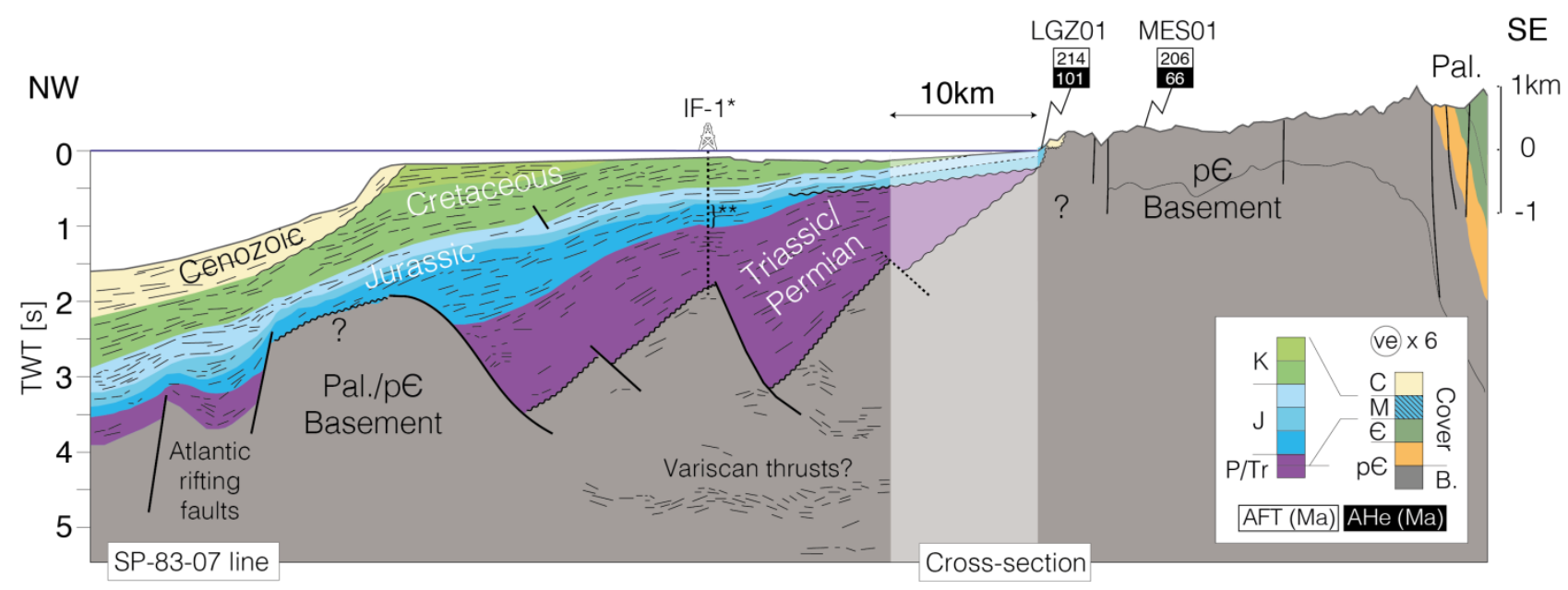

Figure 3. The Sidi Ifni transect: composite cross-section running through the Sidi Ifni area, based on the interpretation of the 2D seismic line SP-83-07 from Gouiza (2011) and from the geological map from Hollard et al. (1985). The seismic line ends ca. $10 \mathrm{~km}$ before the shoreline. The gap (dashed line in figure 2A) was interpolated from the seismic interpretation and the geological map; the LTT ages are projected. IF-1 is projected on the basement high $\left(^{*}\right)$ at 2 second (TWT). The well report does not document traversing Lower Jurassic sediments but only Triassic and Middle Jurassic $\left(^{* *}\right)$. Lower Jurassic sediments are present on the seismic section at the well projection position, but are truncated less than $10 \mathrm{~km}$ to the SE. C: Cenozoic; M: Mesozoic (K: Cretaceous; J: Jurassic; Tr: Triassic); P: Permian; $€$ : Cambrian; $\mathrm{p} €$ : Precambrian. 


\section{Earth ArXiv post-print}

\section{LTT and t-T modeling: Methods and results}

The samples MES01 and LGZ01 were collected from a granite of the Precambrian basement and the Middle Jurassic conglomerate of Lgezira beach, respectively (fig. 4). Apatite crystals within these samples were analysed for apatite fission tracks (AFT) and $(\mathrm{U}-\mathrm{Th}) / \mathrm{He}(\mathrm{AHe})$. The AFT measurements (table 1) were carried-out at Dalhousie University (Halifax, Canada) by B.Louis, and ages were calculated using the external Detector method (Gallagher et al., 1998). The method is described in Louis (2015). The AHe analyses were conducted in Dalhousie University (Halifax, Canada) by R.Kislitsyn, based on K.Farley's technique summarized in Farley (2002).

The two samples produced Triassic AFT ages (206.1 \pm 10.3 and $214.3 \pm 8.8 \mathrm{Ma}$ ) and

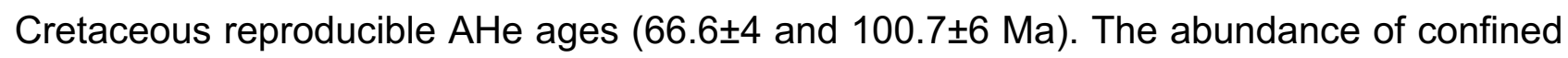
tracks between 12-14 $\mu \mathrm{m}$ (fig. 4 ) is the results of long residence above the Apatite Partial Annealing Zone (APAZ; Bigot-Cormier, 2002) and is compatible with rapid cooling through the APAZ (e.g., Ghorbal et al., 2008). The dispersion of AHe single grain ages suggests a partial opening of the He system (Rougier et al., 2013) between ca.170 and 60 Ma for MES01 and between 140 and 50 Ma for LGZ01. 
Earth ArXiv post-print

\begin{tabular}{|c|c|c|c|c|c|c|c|c|c|c|c|c|}
\hline Samples & $\mathrm{n}$ & $\underset{[\mathrm{ppm}]}{U}$ & $\begin{array}{c}\rho_{\mathrm{s}}\left[\mathrm{x} 10^{5}\right. \\
\left.\operatorname{tr} \mathrm{cm}^{-2}\right] \\
\left(\mathrm{n}_{\mathrm{s}}\right)\end{array}$ & $\begin{array}{c}\rho_{\mathrm{i}}\left[\mathrm{x} 10^{5}\right. \\
\left.\operatorname{tr} \mathrm{cm}^{-2}\right] \\
\left(\mathrm{n}_{\mathrm{i}}\right)\end{array}$ & $\begin{array}{c}\rho_{\mathrm{d}}\left[\mathrm{x} 10^{5}\right. \\
\left.\operatorname{tr} \mathrm{cm}^{-2}\right] \\
\left(\mathrm{n}_{\mathrm{d}}\right)\end{array}$ & $\begin{array}{l}P\left(X^{2}\right) \\
\%\end{array}$ & $\begin{array}{c}\text { AFT Ages } \pm 1 \sigma \\
{[\mathrm{Ma}]}\end{array}$ & $\begin{array}{c}\mathrm{MTL} \pm 1 \sigma \\
{[\mu \mathrm{m}]}\end{array}$ & $\begin{array}{l}\operatorname{Std}_{M T L} \\
{[\mu \mathrm{m}]}\end{array}$ & $\mathrm{n}_{\mathrm{TL}}$ & $\begin{array}{l}\text { Dpar } \\
{[\mu \mathrm{m}]}\end{array}$ & $\begin{array}{l}\text { Std }_{\text {Dpar }} \\
{[\mu \mathrm{m}]}\end{array}$ \\
\hline MES01 & 26 & 25.1 & $\begin{array}{c}2.24 \\
(1430)\end{array}$ & $\begin{array}{c}2.19 \\
(1399)\end{array}$ & $\begin{array}{c}11.4 \\
(6234)\end{array}$ & 25.1 & $206.07 \pm 10.29$ & $11.38 \pm 0.85$ & 1.93 & 21 & 2.23 & 0.82 \\
\hline LGZ01 & 36 & 32.9 & $\begin{array}{l}2.933 \\
(2518) \\
\end{array}$ & $\begin{array}{c}2.86 \\
(2455)\end{array}$ & $\begin{array}{c}11.8 \\
(6234) \\
\end{array}$ & 8.5 & $214.27 \pm 8.85$ & $11.77 \pm 0.31$ & 1.98 & 105 & 2.3 & 0.92 \\
\hline
\end{tabular}

Table 1. Apatite Fission track results. $\mathrm{n}$ is the number of analyzed apatite crystals. $\rho_{\mathrm{s}}$ is the density of spontaneous tracks, $\rho_{i}$ is the density of induced tracks, and $\rho_{d}$ is the density of fossil tracks. $n_{s}, n_{i}$, and $n_{d}$ are the number of tracks used for the density calculation. $P\left(X^{2}\right) \%$ is the Chisquare probability; samples pass the Chi-square test when $\mathrm{P}>5 \%$. AFT ages are central ages with error $\pm 1 \sigma$. MTL is the mean track lengths with error $\pm 1 \sigma$ and standard deviation Sdt $\mathrm{MTL}_{\mathrm{TL}} \mathrm{n}_{\mathrm{TL}}$ is the number of measured track lengths. Dpar is the diameter of etched spontaneous tracks measured parallel to the c-axis and is associated to its standard deviation Sdt Dpar. Zeta $(\zeta)=362.3$ is the correcting factor defined by Fleischer and Hart (1972); $\sigma(\zeta)=8.6$ is the zeta uncertainty (Traditional calibration; Hurford, 1990). 
Earth ArXiv post-print

\begin{tabular}{|c|c|c|c|c|c|c|c|c|c|c|c|}
\hline $\begin{array}{l}\text { Sample } \\
\text { Aliquots }\end{array}$ & $\begin{array}{c}\text { U } \\
{[\mathrm{ppm}]}\end{array}$ & $\begin{array}{c}\text { Th } \\
\text { [ppm] }\end{array}$ & $\begin{array}{l}{ }^{147} \mathrm{Sm} \\
{[\mathrm{ppm}]}\end{array}$ & Th/U & $\begin{array}{c}\mathrm{eU} \\
{[\mathrm{ppm}]}\end{array}$ & $\begin{array}{c}\mathrm{He} \\
\text { [fmol] }\end{array}$ & $\begin{array}{c}\text { Radius } \\
{[\mu \mathrm{m}]}\end{array}$ & $\begin{array}{c}\text { Mass } \\
{[\mu \mathrm{g}]}\end{array}$ & $\begin{array}{c}\text { Uncorrected } \\
\text { He age } \pm 1 \sigma \\
{[\mathrm{Ma}]}\end{array}$ & Ft factor & $\begin{array}{c}\text { Corrected } \\
\text { He age } \pm 1 \sigma \\
{[\mathrm{Ma}]}\end{array}$ \\
\hline MES01_I & 21.8 & 33.1 & 13.3 & 1.5 & 29.5 & 21.9 & 40.5 & 1.9 & $73.0 \pm 4.4$ & 0.65 & $113.0 \pm 6.8$ \\
\hline MES01_II & 18.9 & 29.0 & 9.5 & 1.5 & 25.6 & 30.8 & 54.0 & 4.5 & $48.5 \pm 2.9$ & 0.73 & $66.6 \pm 4.0$ \\
\hline MES01_III & 15.0 & 24.5 & 8.5 & 1.6 & 20.7 & 11.8 & 42.0 & 2.0 & $52.0 \pm 3.1$ & 0.65 & $79.7 \pm 4.8$ \\
\hline MES01_IV & 19.5 & 24.7 & 9.5 & 1.3 & 25.2 & 64.5 & 52.0 & 3.7 & $124.5 \pm 7.5$ & 0.72 & $172.6 \pm 10.4$ \\
\hline MES01_V & 21.1 & 34.1 & 12.6 & 1.6 & 29.0 & 6.8 & 35.0 & 1.0 & $40.8 \pm 2.5$ & 0.59 & $69.2 \pm 4.2$ \\
\hline $\begin{array}{c}\text { MES01 } \\
\text { Mean }\end{array}$ & 20.0 & 31.5 & 11.0 & & & & 44.5 & & & & $100.2 \pm 6.0$ \\
\hline LGZ01_I & 24.2 & 27.1 & 27.4 & 1.1 & 30.6 & 25.5 & 44.0 & 2.6 & $58.9 \pm 3.5$ & 0.68 & $87.0 \pm 5.2$ \\
\hline LGZ01_II & 46.9 & 59.4 & 43.6 & 1.3 & 60.8 & 34.5 & 40.0 & 1.6 & $64.4 \pm 3.9$ & 0.64 & $100.7 \pm 6.0$ \\
\hline LGZ01_III & 32.5 & 55.6 & 30.7 & 1.7 & 45.4 & 74.2 & 45.5 & 3.1 & $96.0 \pm 5.8$ & 0.68 & $140.5 \pm 8.4$ \\
\hline LGZ01_IV & 24.8 & 27.0 & 24.5 & 1.1 & 31.1 & 85.2 & 57.0 & 5.9 & $84.8 \pm 5.1$ & 0.75 & $113.5 \pm 6.8$ \\
\hline LGZ01_V & 21.0 & 30.0 & 26.9 & 1.4 & 28.0 & 11.5 & 41.0 & 2.3 & $33.2 \pm 2$ & 0.65 & $51.1 \pm 3.1$ \\
\hline $\begin{array}{c}\text { LGZ01 } \\
\text { Mean }\end{array}$ & 29.9 & 39.8 & 30.6 & & & & 45.5 & & & & $98.6 \pm 5.9$ \\
\hline
\end{tabular}

Table 2. Result of apatite (U-Th)/He analyses. Five aliquots from each sample were analyzed. AHe ages are corrected using the $\mathrm{Ft}$ factor based on crystal geometries. eU: effective uranium. Mean concentrations, radius, and ages are used as input in t-T modelling. 
Earth ArXiv post-print
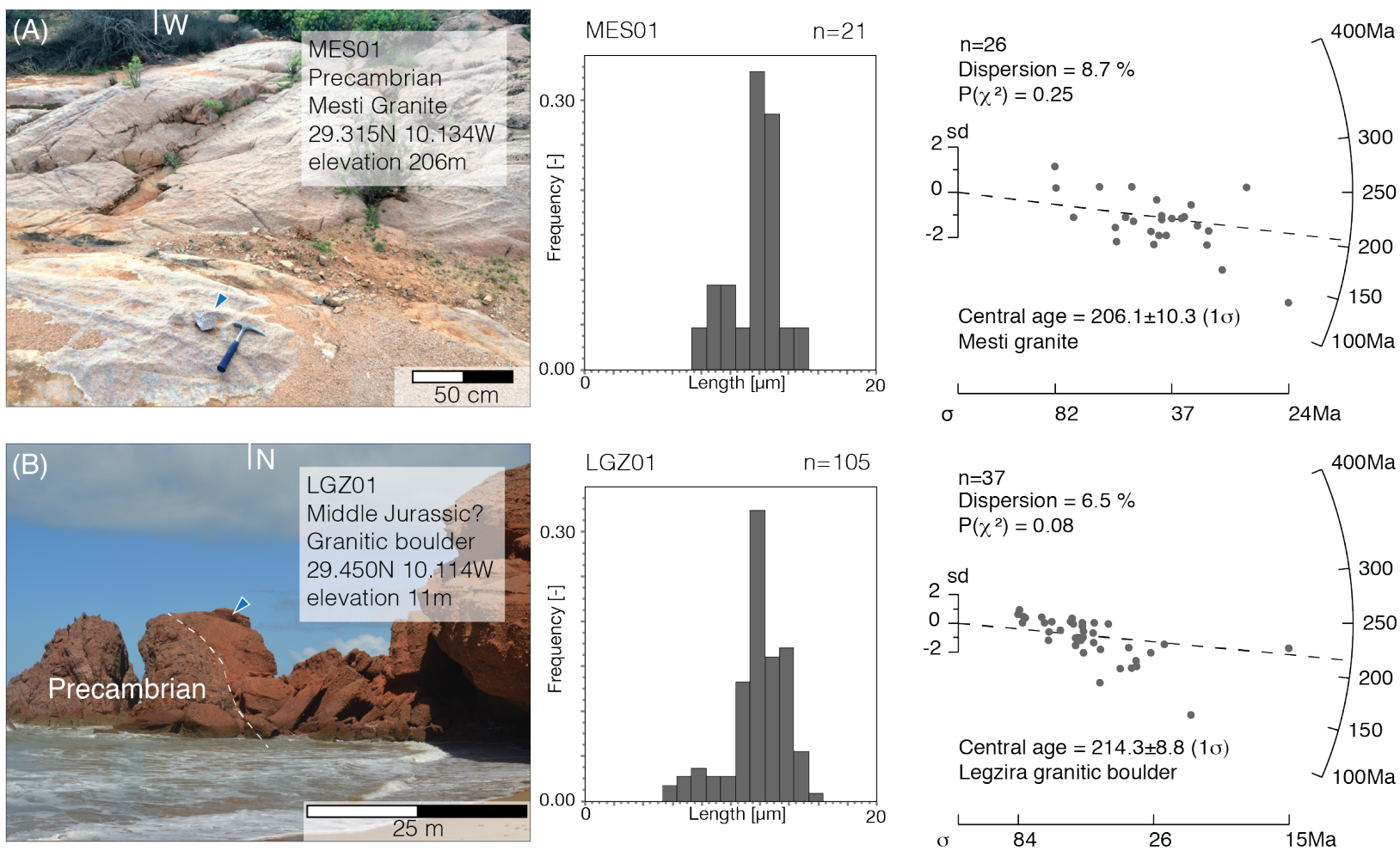

Figure 4. Sampled outcrops (left panel), track length distribution (central panel), and radial plots (bivariate scatterplots; right panel). A) Precambrian granite of the Sidi Ifni area exposed in a riverbed close to the city of Mesti, where MES01 was sampled. B) Middle Jurassic red beds (or older; Arantegui et al., 2016; see appendix) lying unconformably on the Proterozoic basement, located north of the Lgzira village, and where the LGZ01 was sampled. Radial plots were made with RadialPlotter with Linear Transformation (Vermeesch, 2009). sd: standard deviation; $\sigma$ : error with $1 \sigma(\mathrm{Ma})$ (with precision given by $1 / \sigma) ; \mathrm{x}$ : Chi-square probability. 
Time-Temperature (t-T) paths were obtained by modelling AFT lengths, Dpar, and AFT/AHe ages with the inverse modelling HeFTy software (Ketcham, 2005; table 3 and fig. 5). HeFTy runs a Monte Carlo algorithm that generates time-temperature paths that match to a certain extent (Goodness Of Fit, GOF) the input data. In the present study we use AFT models (composed of the AFT single-grain age data and the confined track lengths) and AHe models (composed of the mean AHe corrected age, the chemical composition, and radius of the apatite crystal). Paths are considered 'acceptable' when the GOF for the AFT model is between 5 and $50 \%$, and 'good' when higher than $50 \%$. The 'best fit' path has the highest GOF for both AHe and AFT models.

Five constraints are imposed in this study. Constraint 'a' $\left(300-260^{\circ} \mathrm{C} / 300-295 \mathrm{Ma}\right)$ is based on the end of the Palaeozoic low-grade metamorphism documented by Ruiz et al. (2008) in the western Anti-Atlas (note that the authors described it from 330 to $300 \mathrm{Ma}$, which is on the edge of our modelling window)

Constraint 'b' (200-160 Ma) is based on the Jurassic sediments lying on Palaeozoic and Precambrian rocks in the onshore Sidi Ifni area (Arantegui et al., 2016; see appendix). Importantly, the constraint is set at surface temperature for the granitic boulder $\left(30-10^{\circ} \mathrm{C}\right)$, and close to surface temperatures for the sampled granite $\left(60-20^{\circ} \mathrm{C}\right)$. Indeed, the later must have been protected from Jurassic erosion by the Precambrian (and Palaeozoic?) rock column sitting on top of it. Constraint ' $\mathrm{c}$ ' $\left(110-50^{\circ} \mathrm{C} / \mathrm{AHe}\right.$ age $\left.\pm 10 \mathrm{Ma}\right)$ is based on the produced AHe ages in our samples, according to the temperatures proposed by Shuster et al. (2006). Constraint ' $\mathrm{d}$ ' $\left(30-10^{\circ} \mathrm{C} / 10-0 \mathrm{Ma}\right)$ is based on the fact that the collected samples are currently at the surface. Constraint 'e' $\left(300-10^{\circ} \mathrm{C} / 300-170 \mathrm{Ma}\right)$ helps the numerical solution in finding acceptable and good paths. Moreover, it is based on the fact that prior to deposition we lack geological evidences of the source provenance. Therefore, we cannot define precise constraints. The large constraint 'e' allows the realisations to be at surface as well as at buried temperatures before the deposition of the granitic boulder. 
A. Parameters AFT

Annealing model - Ketcham et al., 2007

C-axis projection - Ketcham et al., 2007, 5.0M

Model c-axis projected lengths - yes

Default initial mean track length - From Dpar $(\mu \mathrm{m})$

Length reduction in standard -0.893

Kinetic parameter - Dpar $(\mu \mathrm{m})$

Population number - one

\title{
Length Data
}

Goodness of fit method - Kuiper's Statistic

\section{Age Data}

Uncertainty mode -1 SE $(\sigma)$

B. Parameters He Apatite

\section{Model parameters}

Calibration - Flowers et al., 2009 (RDAAM Apatite)

Stopping distances - Ketcham et al., 2011

Alpha calculation - Redistribution

\section{Data}

Age to report - Uncorrected (mean age)

Age alpha correction - Ketcham et al., 2011

C. Inverse modelling

\author{
Search Method - Monte Carlo \\ Acceptable Path (GOF) - 0.05 \\ Good Path (GOF) - 0.5 \\ Subsegment spacing - Random \\ Ending condition - Path tried $=1000000$

\section{Segment parameters} \\ Path between constraints - Monotonic consistent \\ Halve - 2 times \\ Randomizer style - Episodic \\ No imposed maximum $\mathrm{dt} / \mathrm{dt}$
}

Table 3. Input parameters used for both simulations, which are performed with the HeFTy software (version 1.8.2; Apatite to Zircon; Ketcham, 2005). A) Parameters used for the AFT models. Cf irradiation, see Donelick and Miller (1991); Dpar is the diameter of etched spontaneous tracks measured parallel to the c-axis and is used as a proxy for the chemical composition of apatite and therefore for the annealing properties (Donelick et al., 1999); Kuiper's statistic, see Press et al. (1992); SE stands for standard error. B) Parameters used for the AHe models. C) Parameters used in the inverse modelling. 


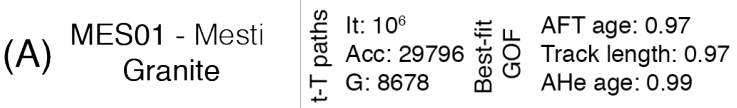
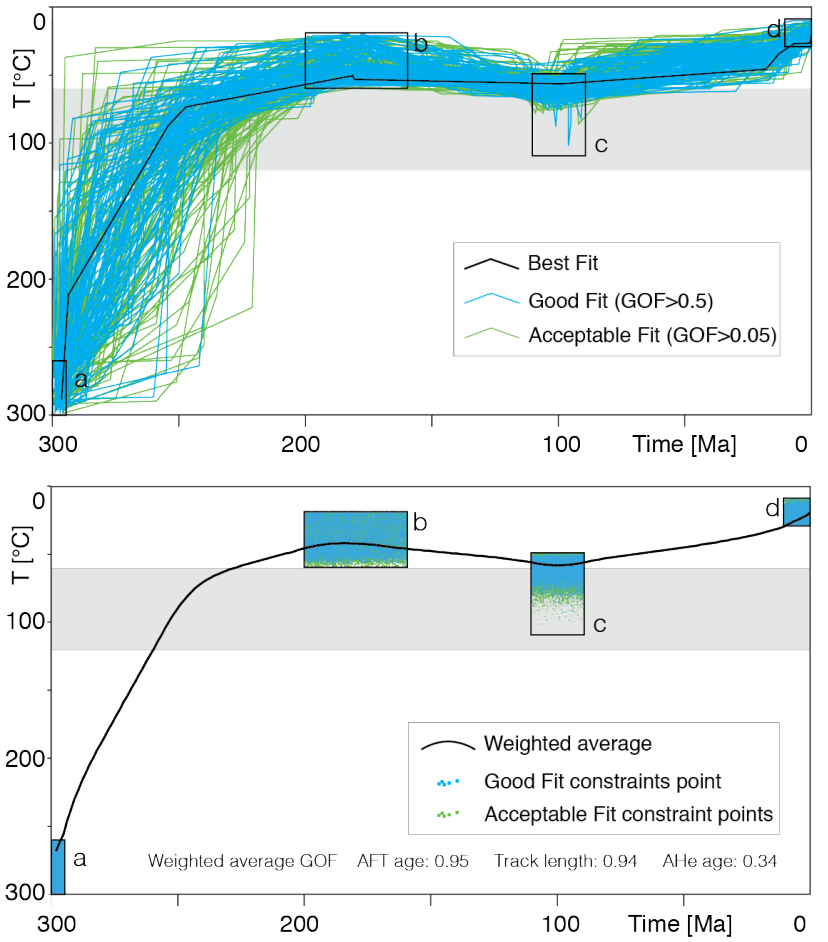

Constraints (user defined time/temperature windows)

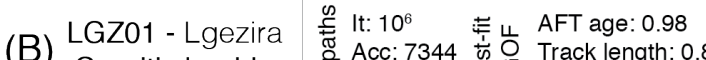

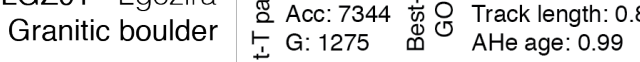
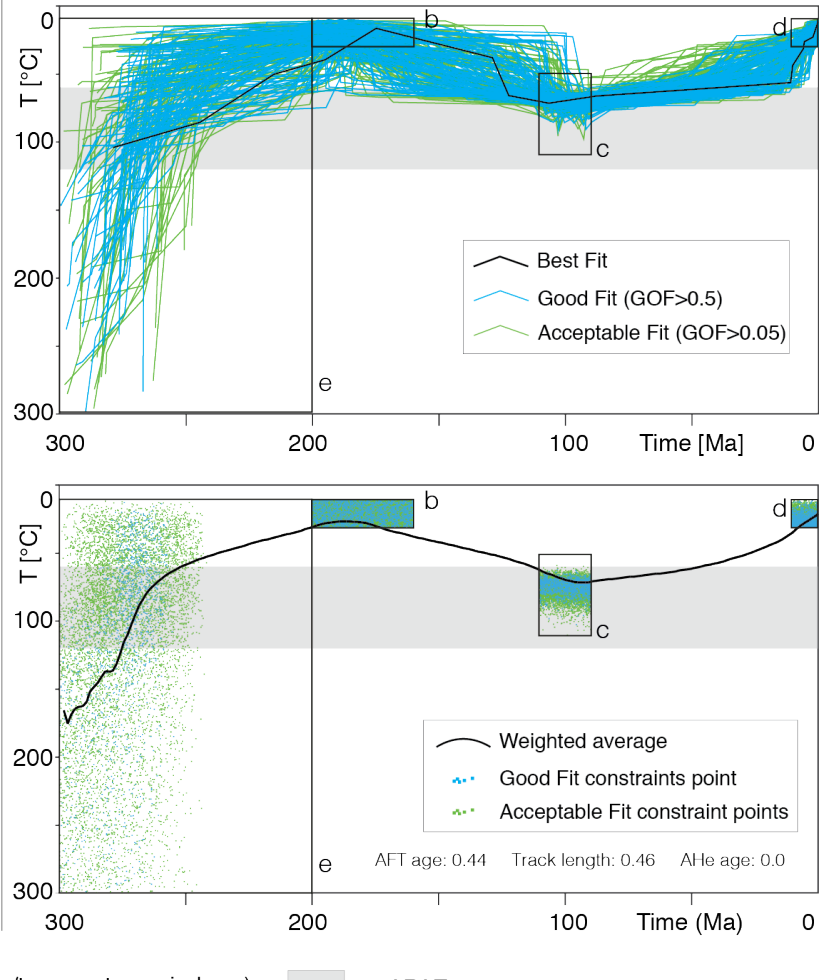

APAZ

Figure 5. Results of t-T modelling for A) MES01 and B) LGZ01. Results are displayed with up to 200 curves for both good and acceptable goodness of fit (GOF) and the best-fit t-T path (upper panels) or with the constraint points and the weighted average (lower panels). Forward modelling was used to reproduce the weighted average curves in order to obtain their GOF values. See modelling parameters in table 3. It: number of iterations for the inverse modelling; Acc: acceptable paths; G: good paths. APAZ: Apatite Partial Annealing Zone. 
The thermal modelling results are characterised by two cooling events, of significantly different amplitudes, separated by a heating phase. Results for both samples are very similar (fig. 5). The best-fit t-T path of MES01 shows a cooling event ending in the Early/Middle Jurassic (cooling of $250 \pm 10^{\circ} \mathrm{C}$ between ca. 300 and $180 \mathrm{Ma}$ ), a subsequent heating to temperatures of ca. $50-60^{\circ} \mathrm{C}$ at the Early to Late Cretaceous boundary (heating of ca. $10^{\circ} \mathrm{C}$ between ca. 180 and $100 \mathrm{Ma}$ ), followed by the second and last cooling episode (cooling of ca. $30 \pm 10^{\circ} \mathrm{C}$ between 100 and $0 \mathrm{Ma}$ ). The timing of heating and cooling episodes observed for the granitic boulder is similar, but this sample reached a higher temperature (of ca. $70^{\circ} \mathrm{C}$ ) during the heating episode. Between the two samples, the weighted averages are nearly identical, with a Permian to Early/Middle Jurassic cooling episode, Late Jurassic to Early Cretaceous heating episode, and Late Cretaceous to present-day cooling episode. However, the two samples are characterised by different temperature maxima and minima during each phase. At $170 \mathrm{Ma}$, temperatures are $20^{\circ} \mathrm{C}$ cooler in the boulder, while the boulder reached temperatures ca. $10^{\circ} \mathrm{C}$ higher than the granite sample at $100 \mathrm{Ma}$. We used the forward modelling option of HeFTy in order to obtain the GOF of the weighted averages (fig. 5). While the AFT and AHe data of MES01 are reproduced, the GOF value of the LGZ01 AHe age is 0 . When we increase the temperatures of ca. $10^{\circ} \mathrm{C}$ at $95 \mathrm{Ma}$, the forwarded paths yield GOF values significantly higher, especially with LGZ01, for which the AHe age GOF value reached 0.98 . We thereafter use the weighted average results to describe the evolution of the Sidi Ifni transect, with $10^{\circ} \mathrm{C}$ added at ca. $95 \mathrm{Ma}$ for LGZ01.

Previous LTT and t-T modelling studies carried-out in the Sidi Ifni area (figs. 2A and 6; Sebti et al., 2009; Sebti, 2011; Ruiz et al., 2011; Sehrt et al., 2017) concluded that a Carboniferous-Early Cretaceous km-scale exhumation $(8-6 \mathrm{~km})$ was followed by a post-rift burial $(1-2 \mathrm{~km})$ during the Late Cretaceous, and by an exhumation $(2-2.5 \mathrm{~km})$ during the 
Cenozoic. Our best-fit results show similar trend and amplitudes as the previous studies in the Sidi Ifni area (fig. 6 and references therein), with two cooling episodes separated by a heating event; the timing, however, is significantly different. The main reason lies in the age of the Mesozoic sediments used to constrain the curves, which were assumed to be Early Cretaceous but have now been shown to be Middle Jurassic (Arantegui et al., 2016; see appendix). It is worth noting that three of the best-fit curves from Sebti (2011) also show the post-Variscan exhumation ending during the Jurassic. However, the related exhumation was interpreted as ending in the Early Cretaceous because of all the other modelled t-T paths (good and acceptable realisations). 
Earth ArXiv post-print

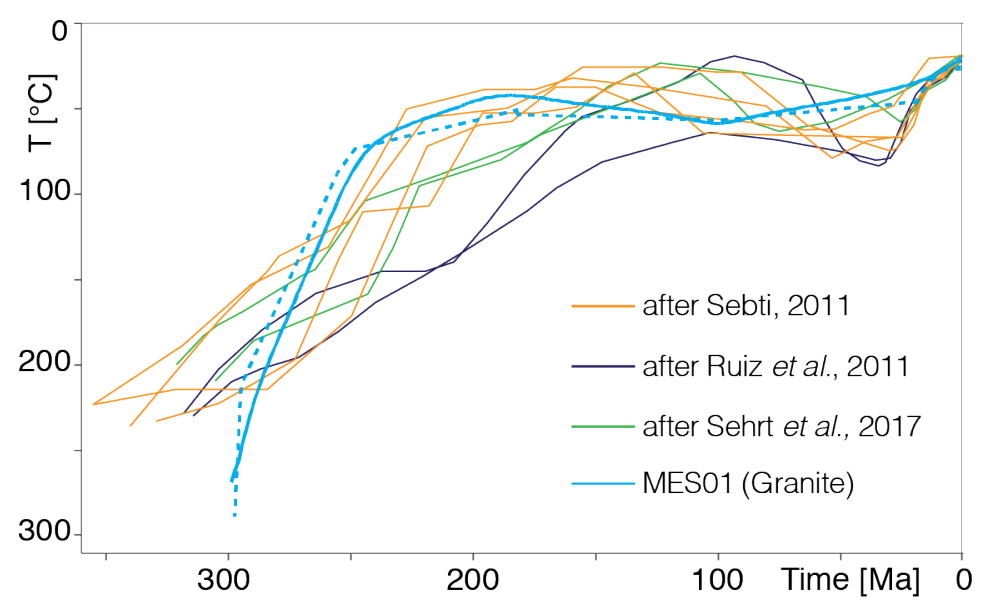

Figure 6. Best-fit (dashed) and weighted average t-T paths of MES01 compared to the best-fit $\mathrm{t}-\mathrm{T}$ paths obtained in previous studies for samples of the Precambrian basement of the Sidi Ifni area. 


\section{Discussion}

\section{Post-Variscan evolution of the Sidi Ifni transect}

Integrating results from LTT and t-T modelling with the backstripping of Ifni-1 well (Gouiza, 2011), we reconstructed the evolution of the Sidi Ifni transect (fig. 7). Following the Variscan orogeny (fig. 7A), a major exhumation (ca. $7.5 \mathrm{~km}$, using a geothermal gradient of $25^{\circ} \mathrm{C} / \mathrm{km}$ and a surface temperature of $20^{\circ} \mathrm{C}$; e.g., Sehrt et al., 2017) occurred in the onshore domain during the Permian. This exhumation is also documented in the majority of LTT studies conducted in the Anti-Atlas (e.g., Sebti et al., 2009; Oukassou et al., 2013). Although offshore Permian sediments are undifferentiated from the base of the syn-rift sediments, we consider the western part of the transect to have started subsiding during the Permian.

During the Triassic and Early/Middle Jurassic, the upward movement of the eastern part of the transect continued (ca. $1 \mathrm{~km}$, using the above-mentioned geotherm), persisting until ca. $180 \mathrm{Ma}$ (fig. 7B). This occurs either 15-10 Ma after the continental breakup (Early Jurassic; ca. 195-190 Ma; Sahabi et al., 2004; Labails et al., 2010; Lundin and Doré, 2017) or $10 \mathrm{Ma}$ before the continental breakup (Middle Jurassic; ca. 170; Klitgord et al., 1986; Davison et al., 2005; Gouiza et al., 2010), as the onset of drifting in the Central Atlantic is still debated. The related denudation event shed important volumes of sediments to the west, as attested by the sediments accommodated by the SE dipping normal faults (Le Roy and Piqué, 2001).

The unconformity recognised in the present-day offshore domain between the Triassic and the Middle Jurassic is correlated onshore to the unconformity between Palaeozoic/Precambrian and Middle Jurassic sediments. We consider that the Early/Middle Jurassic exhumation episode in the western Anti-Atlas affected also the previously subsiding domain, reaching at least the vicinity of Ifni-1 well. Erosion affected the Palaeozoic series and the Sidi Ifni granite (fig. 7C), until the exhumation ended in the 
Early/Middle Jurassic. The sampled granitic boulder provenance may be the western AntiAtlas, as both samples share a similar $\mathrm{t}-\mathrm{T}$ evolution.

During the Late Jurassic to Early Cretaceous (fig. 7D), important burial occurred in the offshore and onshore domains (between ca. 0.6 and $2 \mathrm{~km}$ ). Related sediments are characterised by neritic clastics and carbonates (Ifni-1) and by a fluvial dominated environment (Sehrt et al., 2017). This event is recorded in the Ifni-1 well by an acceleration of the total subsidence rates, from ca. 0.02 to $0.03 \mathrm{~km} / \mathrm{Ma}$ (Gouiza, 2011). A concomitant burial episode is observed in the entire Anti-Atlas (Gouiza et al., 2017).

Burial ends between the Early and Late Cretaceous at ca. $100 \mathrm{Ma}$ and is followed by exhumation from Late Cretaceous onwards (between ca. 1 and $2 \mathrm{~km}$ ). The lack of Upper Cretaceous sediments in the Ifni- 1 well and up-dip truncations of the Lower Cretaceous reflections indicate that the Late Cretaceous to Cenozoic exhumation reached the presentday offshore domain (fig. 7E) and that Lower Cretaceous sediments extended farther into the western Anti-Atlas. 
(E) Present Day [0 Ma]
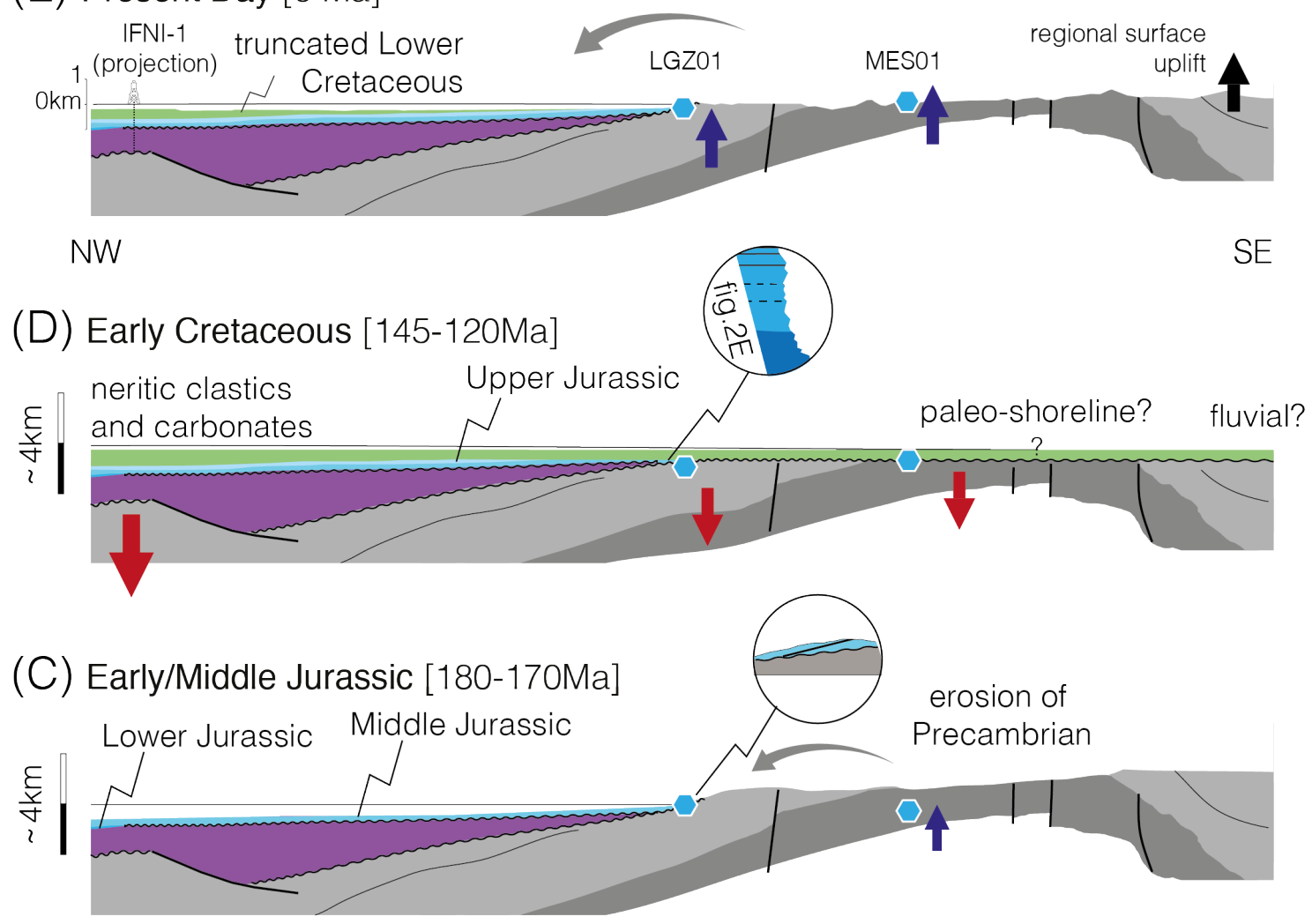

(B) Late Triassic [220-200Ma]

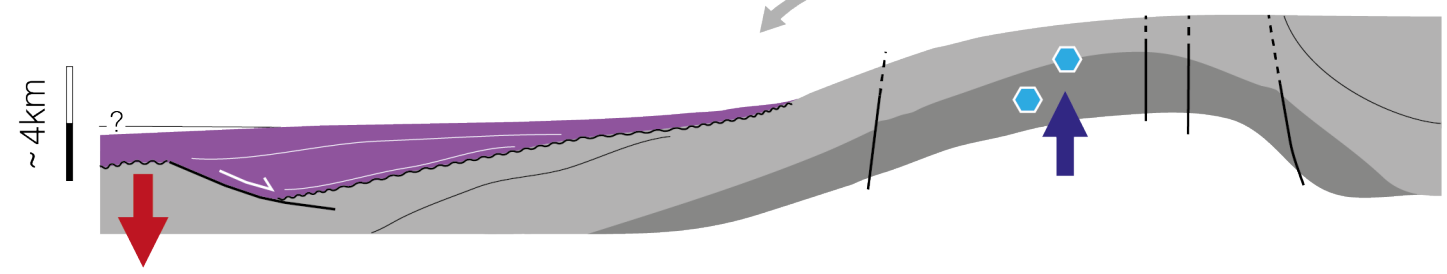

(A) Variscan [360-290Ma]

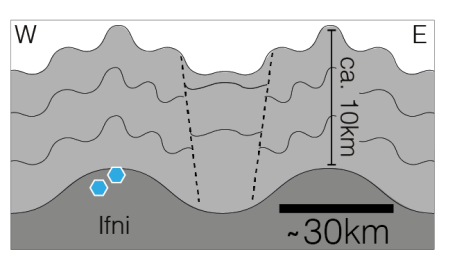

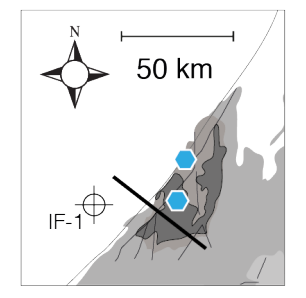

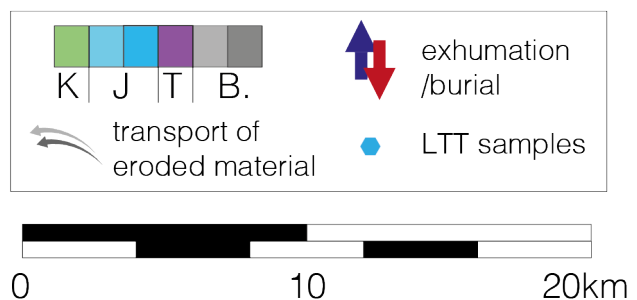

Figure 7. Conceptual model of the geological evolution of the Sidi Ifni transect; (E) is simplified from figure 3. Vertical movements estimated from t-T modelling results of MES01 and LGZ01 and backstripping of the Ifni-1 well (in Gouiza, 2011). The description of each stage is in the text. Horizontal scale is for B) to E) (no vertical exaggeration). B: undifferentiated basement offshore and Precambrian/Palaeozoic basement onshore; T: Triassic/Permian; J: Lower, Middle, and Upper Jurassic; K: Cretaceous. Thickness in the offshore domain is here estimated from Ifni-1 well, hence no Early Jurassic at the well position was considered. Note that the granitic boulder has likely been sourced from the western Anti-Atlas as suggested in the text, and not necessarily from the Sidi Ifni granitic dome. 


\section{Comparing the Sidi Ifni transect to other transects along the Moroccan rifted margin}

Five cross-sections perpendicular to the Moroccan rifted margin, across offshore and onshore Atlantic basins are compared to the present-day Sidi Ifni transect (fig. 8). To compare the geological evolutions, we use published t-T models and subsidence curves along these transects (fig. 8).

The Doukkala, Rabat Offshore, and Essaouira transects (figs. 8A, B and C, respectively) all depict a Triassic or Jurassic unconformity over the basement, onshore as well as offshore, and a relatively thick Mesozoic sedimentation (up to 2-3 km). The Upper Cretaceous reflections are truncated at the present-day continental shelf edge (Hafid et al., 2008), which is attributed to Cenozoic tectonics. In the Meseta and High Atlas, LTT studies and $\mathrm{t}-\mathrm{T}$ models have documented a similar kinematic evolution of vertical movements (e.g., Ghorbal et al., 2008; Domenech et al., 2016). The presently outcropping Variscan rocks in the Meseta were close to the surface during the Permian/Late Triassic, followed by burial until the Middle Jurassic, exhumation in the Late Jurassic/Early Cretaceous, renewed burial during the Late Cretaceous and a final exhumation in the Cenozoic.

Both Anti-Atlas sections (figs. 8D and E) show a fairly thick Mesozoic package (between 2 and $5 \mathrm{~km}$ ) at the western flank of the belt, with two to three unconformities: following the Variscan folding, within the Jurassic and at the base of the Cenozoic. In the Anti-Atlas, Gouiza et al. (2017) and this study document a similar thermal evolution, although different from the one described in the Meseta (e.g., Ghorbal et al., 2008).

The differences in post-Variscan thermal evolutions of the Meseta/High Atlas and AntiAtlas highlight several shifts of source areas for the sediments delivered to the Atlantic and coastal basins between the Middle and Late Jurassic and between the Early and Late Cretaceous.

Finally, the Dakhla section (fig. $\mathbf{8 F}$ ) shows that no sediments are preserved prior to the Early Cretaceous (Ranke et al., 1982; Saddiqi et al., 2015) west of the Mauritanides/ 
Earth ArXiv post-print

Reguibat Shield. The thickness of the Cretaceous deposits may have reached $2 \mathrm{~km}$, unconformably overlain by Palaeocene sediments (Ranke et al., 1982). The documented kinematic evolution (e.g., Leprêtre et al. 2015) is also different from those of other segments, showing subsidence from the Permian to the Triassic and exhumation from Jurassic onwards for most of the Reguibat Shield, with locally shorter and milder exhumation and subsidence episodes (e.g., Leprêtre et al., 2015). 

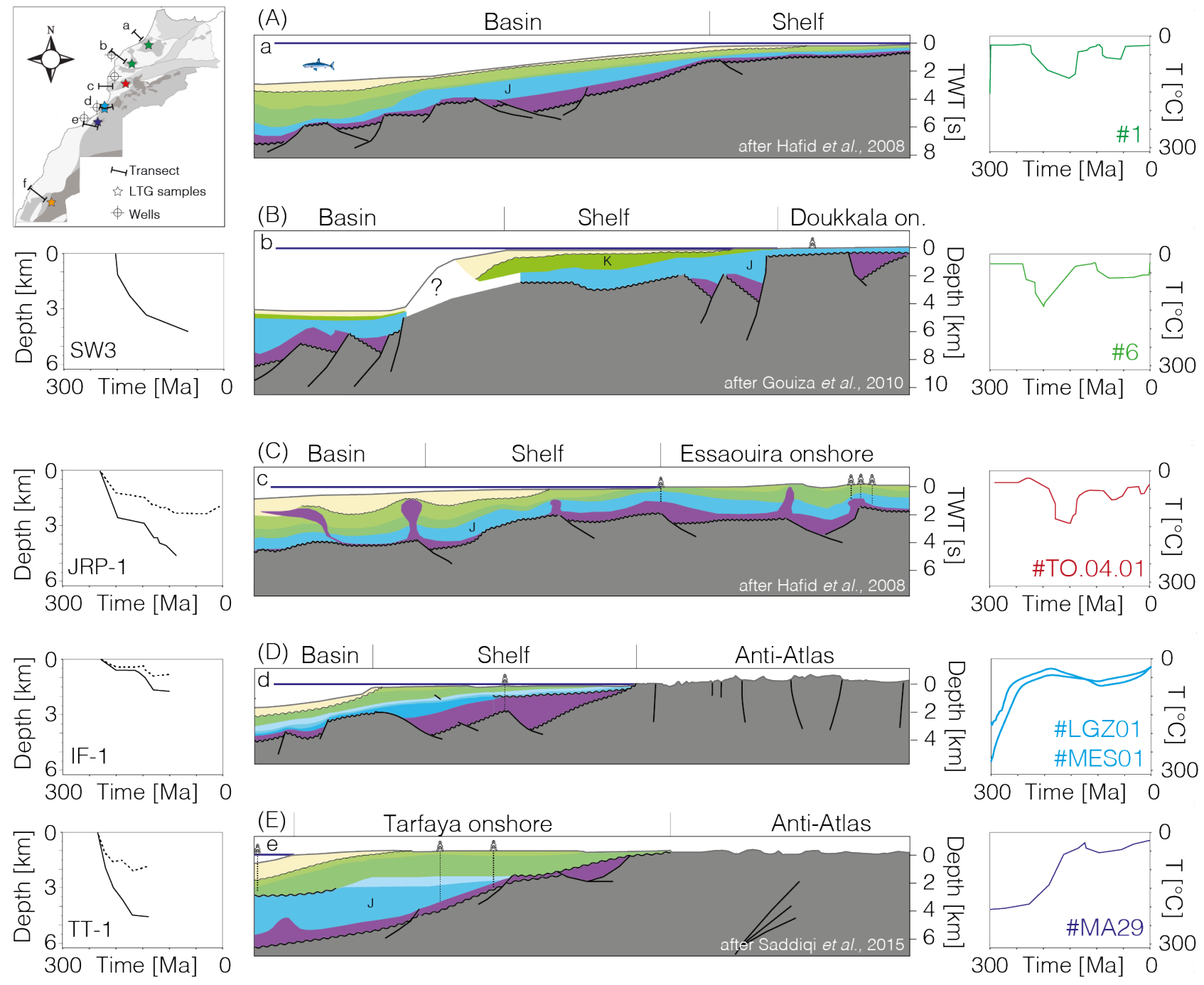

$(\mathrm{E})$

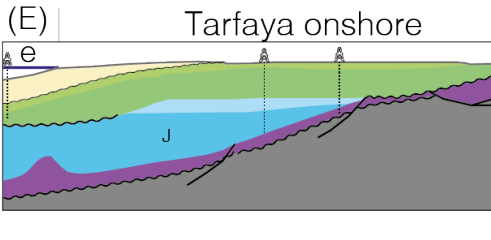

Anti-Atlas

$$
\begin{aligned}
& \text { Backstripping results (in } \mathrm{km} \text { ) } \\
& \text { — total subsidence } \\
& \text {...... tectonic subsidence } \\
& \mathrm{t}-\mathrm{T} \text { results }\left(\text { in }{ }^{\circ} \mathrm{C}\right) \\
& \frown \text { weighted averages } \\
& \frown \text { best fit }
\end{aligned}
$$
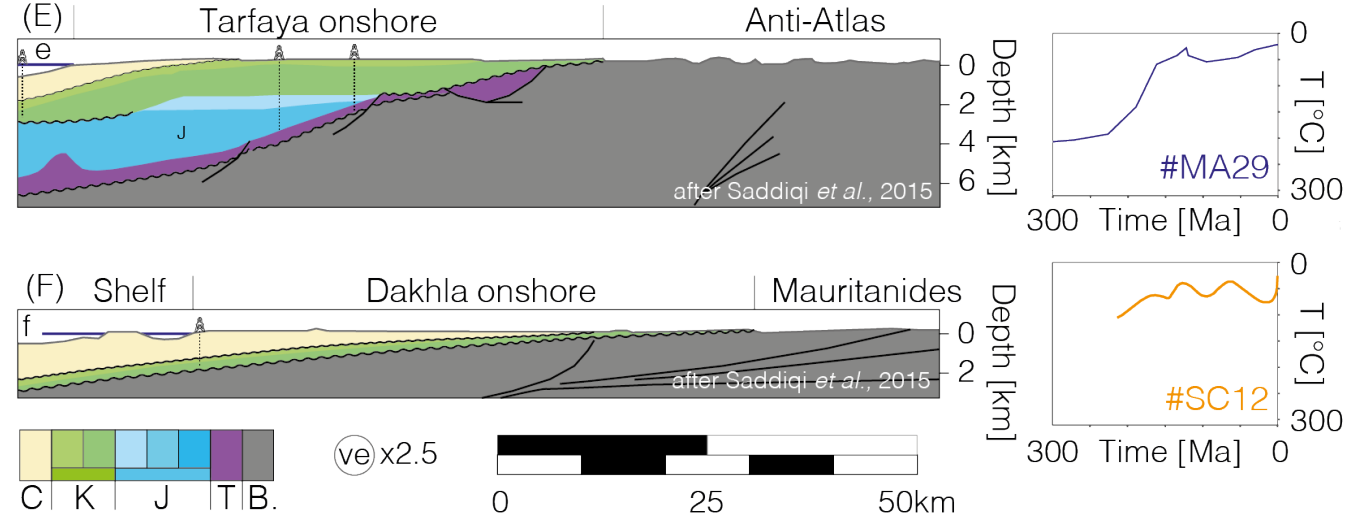

Figure 8. Present-day 2D architecture of the Moroccan passive margin (central panels), selected subsidence and backstripping curves (left panels), and t-T modelling (right panels) results. Note that cross-sections a and $c$ are in time. See location map for orientation. C: Cenozoic; same stratigraphy legend as figure 7. The letters " $J$ " and "K" are shown on the sections if the Jurassic or Cretaceous are locally undifferentiated. The t-T best-fit results of samples 1/6, TO.04.01 and MA29 are from Ghorbal et al., 2008, Ghorbal, 2009 and Sehrt et al., 2017, respectively. The t-T weighted average results of samples LGZ01/MES01 and SC12 are from the present work and Leprêtre et al., 2015, respectively. The subsidence curves from wells SW3 (synthetic), JRP-1 and IF-1/TT-1 are from Gouiza et al., 2010, Bouatmani et al., 2007 and Gouiza, 2011, respectively. 


\section{Earth ArXiv post-print}

\section{Vertical movements mechanisms}

The pre-rift exhumation is a result of the erosion following the Variscan orogeny (postorogeny collapse), while the mechanisms responsible for the syn- and early post-rift exhumation remain unconstrained. The observed syn-rift exhumation is not linked to rift shoulder uplift, as proposed for the Anti-Atlas by previous authors (e.g.,Oukassou et al., 2013; Soulaimani et al., 2014), for two reasons: (1) the Permian to Jurassic exhumation started before the initiation of rifting and (2) Late Triassic sediments are well represented east of the Atlantic faults (offshore Sidi Ifni). However, we do not discard a surface uplift as the majority of $\mathrm{t}-\mathrm{T}$ models in the Anti-Atlas document an exhumation during the Central Atlantic syn-rift period.

The post-rift burial shown in the evolution of the Sidi Ifni transect is a results of the large scale denudation of areas in the north (Meseta/Western High Atlas; e.g., Bertotti and Gouiza, 2012) and in the south (Reguibat Shield; e.g.,Leprêtre et al., 2015), routing sediments over the Anti-Atlas and towards the offshore. The Late Cretaceous exhumation may be explained by crustal horizontal stresses propagating following the onset of the South Atlantic drift (e.g., Michard et al., 2008a; Ghorbal et al., 2008). 


\section{Conclusions}

The $\mathrm{t}-\mathrm{T}$ modelling results constrained by Middle Jurassic stratigraphy preserved along the coast allowed the reconstruction of the geological evolution of the Sidi Ifni transect. Results indicate the exhumation of the onshore domain of the transect by ca. $7.5 \mathrm{~km}$ between the end of the Variscan orogeny and the Early/Middle Jurassic. Erosion affected the Palaeozoic series and eventually reached the Precambrian basement. Eroded material was routed to the subsiding Mesozoic basin to the northwest. Rocks along the transect was subsequently buried to a depth of 0.6 to $2 \mathrm{~km}$ during the Late Jurassic and the Early Cretaceous. The burial event is documented in the offshore well (IF-1) by an acceleration of the total subsidence rates. From late Early/Late Cretaceous onwards, the transect rocks were exhumed by 1 to $2 \mathrm{~km}$ onshore, while the Lower Cretaceous deposits in the continental shelf were exposed and eroded (truncated reflections).

The comparison of the Sidi Ifni transect to other transects along the rifted margin of Morocco highlights changes in the architecture of the offshore Mesozoic deposit. We show here that the above defined segments along the margin underwent significantly different kinematic evolutions, with specific vertical movement patterns in the hinterland and basins. The comparison of the t-T models of the Meseta/High Atlas to the Anti-Atlas shows two major shifts in the active sediment source areas during the Jurassic and Cretaceous periods. 


\section{Acknowledgments}

The authors, all NARG members (North Africa Research Group), thank the ONHYM (Office National des Hydrocarbures et des Mines) for field work support and access to internal reports. We are thankful to B.Louis, I.Coutand, and R.Kislitsyn of Dalhousie University (Halifax, Canada) for the produced radiometric ages. M.Gouiza (Leeds, UK) is thanked for providing extra material used in this work.

M.Simmons (NHM, London), B.Granier (Brest, France), R.Gatto and S.Monari (Padua, Italy) are thanked for their work on the palaeontology data presented in the appendix.

We thank M.Gouiza and an anonymous reviewer for their constructive comments that significantly helped to improve the present work.

\section{Funding}

This work was supported by the Integrated for Solid Earth Sciences (ISES; PhD project funding of the first author) and by the North Africa Research Group (NARG). 


\section{References}

Amidon, W.H., Roden-Tice, M., Anderson, A.J., McKeon, R.E. and Shuster, D.L., 2016. Late Cretaceous unroofing of the White Mountains, New Hampshire, USA: An episode of passive margin rejuvenation?: Geology, 44, 415-418.

Arantegui, A., Luber, T., Charton, R., Simmons, M., Bertotti, G. and Redfern, J., 2016. Temporal and spatial evolution of Mesozoic drainage systems feeding the deepwater Atlantic passive margin of Morocco: Tarfaya Basin: Conference Abstract, $32^{\text {nd }}$ Meeting of Sedimentology, IAS Marrakech, 1-2.

Bertotti, G. and Gouiza, M., 2012. Post-rift vertical movements and horizontal deformations in the eastern margin of the Central Atlantic: Middle Jurassic to Early Cretaceous evolution of Morocco: International Journal of Earth Sciences, 101, 21512165.

Bigot-Cormier, F., 2002. La surrection du massif cristallin externe de l'Argentera (FranceItalie) et ses relations avec la déformation pliocène de la marge Nord-Ligure : Arguments thermo-chronologiques (traces de fission), géomorpho-logiques et interprétations de sismique marine: PhD Thesis, Université Nice Sophia Antipolis, 354 pp.

Bouatmani, R., Chakor Alami, A. and Medina, F., 2007. Subsidence, évolution thermique et maturation des hydrocarbures dans le bassin d'Essaouira (Maroc): apport de la modélisation: Bulletin Institut Scientifique-Rabat, 29, 15-36.

Burkhard, M., Caritg, S., Helg, U., Robert-Charrue, C. and Soulaimani, A., 2006. Tectonics of the Anti-Atlas of Morocco: Comptes Rendus Geoscience, 338, 11-24.

Choubert, G., Faure-Muret, A. and Hottinger, L., 1966. Apercu Geologique du Bassin Cotier de Tarfaya. In: Le Bassin Cotier de Tarfaya (Maroc meridional), Tome I, Stratigraphie, Notes et Memoires du Service Geologique, 115, 7-222. 
Davison, I., 2005, Central Atlantic margin basins of North West Africa: Geology and hydrocarbon potential (Morocco to Guinea): Journal of African Earth Sciences, 43, 254274.

Domènech, M., Teixell, A., Babault, J. and Arboleya, M.-L., 2015. The inverted Triassic rift of the Marrakech High Atlas: A reappraisal of basin geometries and faulting histories: Tectonophysics, 663, 177-191.

Donelick, R.A. and Miller, D.S., 1991. Enhanced TINT fission track densities in low spontaneous track density apatites using 252 Cf-derived fission fragment tracks: A model and experimental observations: Nuclear Tracks and Radiation Measurements, 18, 301307.

Donelick, R.A., Ketcham, R.A. and Carlson, W.D., 1999. Variability of apatite fission-track annealing kinetics II. Crystallographic orientation effects: American Mineralogist, 84, 12241234.

Farley, K.A., 2002. (U-Th)/He Dating: Techniques, Calibrations, and Applications: Reviews in Mineralogy and Geochemistry, 47, 819-844.

Fleischer, R.L. and Hart, H.R., 1972. Fission track dating: techniques and problems. Calibration of Hominoid Evolution, 135, 170.

Flowers, R.M., Ketcham, R.A., Shuster, D.L. and Farley, K.A., 2009. Apatite (U-Th)/He thermochronometry using a radiation damage accumulation and annealing model: Geochimica et Cosmochimica Acta, 73, 2347-2365.

Frizon de Lamotte, D., Leturmy, P., Missenard, Y., Khomsi, S., Ruiz, G., Saddiqi, O., Guillocheau, F. and Michard, A., 2009. Mesozoic and Cenozoic vertical movements in the Atlas system (Algeria, Morocco, Tunisia): An overview: Tectonophysics, 475, 9-28.

Fullea, J., Fernàndez, M., Zeyen, H. and Vergés, J., 2007. A rapid method to map the crustal and lithospheric thickness using elevation, geoid anomaly and thermal analysis. 
Application to the Gibraltar Arc System, Atlas Mountains and adjacent zones: Tectonophysics, 430, 97-117.

Gallagher, K., Brown, R. and Johnson, C., 1998. Fission track analysis and its applications to geological problems: Annual Review of Earth and Planetary Sciences, 26, $519-572$.

Ghorbal, B., Bertotti, G., Foeken, J. and Andriessen, P., 2008. Unexpected Jurassic to Neogene vertical movements in 'stable' parts of NW Africa revealed by low temperature geochronology: Terra Nova, 20, 355-363.

Ghorbal, B., 2009. Mesozoic to Quaternary thermo-tectonic evolution of Morocco (NW Africa): PhD Thesis, Vrije Universiteit Amsterdam, 231 pp.

Gouiza, M., 2011. Mesozoic source-to-sink systems in NW Africa: Geology of vertical movements during the birth and growth of the Moroccan rifted margin: PhD Thesis, Vrije Universiteit Amsterdam, 192 pp.

Gouiza, M., Bertotti, G., Hafid, M. and Cloetingh, S., 2010. Kinematic and thermal evolution of the Moroccan rifted continental margin: Doukkala-High Atlas transect: Tectonics, 29, 1-22.

Gouiza, M., Charton, R., Bertotti, G., Andriessen, P. and Storms, J.E.A., 2017. PostVariscan evolution of the Anti-Atlas belt of Morocco constrained from low-temperature geochronology: International Journal of Earth Sciences, 106, 593-616.

Hafid, M., Tari, G., Bouhadioui, I., Moussaid, El, E., Echarfaoui, H., Aït Salem, H., Nahim, M. and Dakki, M., 2008. Atlantic Basins. In: Continental Evolution: The Geology of Morocco, Springer Science \& Business Media.

Helg, U., Burkhard, M., Caritg, S. and Robert-Charrue, C., 2004. Folding and inversion tectonics in the Anti-Atlas of Morocco: Tectonics, 23, TC4006. 
Hollard, H., Choubert, G., Bronner, G., Marchand, J. and SOUGY, J., 1985. Carte Géologique du Maroc, scale 1/1000000 (2 sheets): Notes et Mémoires du Service Géologique du Maroc, 260.

Hurford, A.J., 1990. Standardization of Fission Track Dating Calibration: Recommendation by the Fission Track Working Group of the I.O.G.S. Subcommission on Geochronology: Chemical Geology, 80, 171-178.

Japsen, P., Bonow, J.M., Green, P.F., Chalmers, J.A. and Lidmar-Bergström, K., 2006. Elevated, passive continental margins: Long-term highs or Neogene uplifts? New evidence from West Greenland: Earth and Planetary Science Letters, 248, 330-339.

Japsen, P., Green, P.F., Bonow, J.M., Hinchey, A.M. and Wilton, H.C., 2016. Burial and exhumation history of the Labrador- Newfoundland margin: first observations: Geologic survey of Denemark and Greenland bulletin, 35, 91-94.

Jelinek, A.R., Chemale, F., Jr, van der Beek, P.A., Guadagnin, F., Cupertino, J.A. and Viana, A., 2014. Denudation history and landscape evolution of the northern East-Brazilian continental margin from apatite fission-track thermochronology : Journal of South American Earth Sciences, 54, 158-181.

Ketcham, R.A., 2005. Forward and Inverse Modeling of Low-Temperature Thermochronometry Data: Reviews in Mineralogy and Geochemistry, 58, 275-314.

Ketcham, R.A., Carter, A., Donelick, R.A., Barbarand, J. and Hurford, A.J., 2007. Improved modeling of fission-track annealing in apatite: American Mineralogist, 92, 799810.

Ketcham, R.A., Gautheron, C. and Tassan-Got, L., 2011. Accounting for long alphaparticle stopping distances in (U-Th-Sm)/He geochronology: Refinement of the baseline case: Geochimica et Cosmochimica Acta, 75, 7779-7791. 
Klitgord, K.D., Schouten, H., Vogt, P.R. and Tucholke, B.E., 1986. Plate kinematics of the Central Atlantic. In: The Western North Atlantic Region: The Geology of North America, Geological Society of America.

Labails, C., Olivet, J.-L., Aslanian, D. and Roest, W.R., 2010. An alternative early opening scenario for the Central Atlantic Ocean: Earth and Planetary Science Letters, 297, 355368.

Le Roy, P. and Piqué, A., 2001. Triassic-Liassic Western Moroccan synrift basins in relation to the Central Atlantic opening: Marine Geology, 172, 359-381.

Leprêtre, R., Missenard, Y., Barbarand, J., Gautheron, C., Saddiqi, O. and Pinna-Jamme, R., 2015. Post-rift history of the eastern Central Atlantic passive margin: insights from the Saharan region of South Morocco: American Geophysical Union, 1-58.

Louis, B., 2015. Late Cenozoic Upper-Crustal Cooling History of the Shuswap Metamorphic Complex, Southern Canadian Cordillera, British Columbia: New Insights From Low-Temperature Multi- Thermochronometry and Inverse Thermal Modeling: MSc Thesis, Dalhousie University, 226 pp.

Lundin, E.R. and Doré, A.G., 2017. The Gulf of Mexico and Canada Basin: Genetic Siblings on Either Side of North America: GSA Today, 27, 4-11.

Martinis, B. and Visintin, V., 1966. Données géologiques sur le bassin sédimentaire côtier de Tarfaya (Maroc méridional): Bassins sédimentaires du Littoral africain, In: Bassins sédimentaires du littoral africain. Association des Services Géologiques Africain.

Michard, A., Saddiqi, O., Chalouan, A. and Frizon de Lamotte, D., 2008a. Continental Evolution: Continental Evolution: The Geology of Morocco. Springer Science \& Business Media, 426 pp.

Michard, A., Hoepffner, C., Soulaimani, A. and Baidder, L., 2008b. The Variscan Belt. In: Continental Evolution: The Geology of Morocco. Springer Science \& Business Media. 
Oukassou, M., Saddiqi, O., Barbarand, J., Sebti, S., Baidder, L. and Michard, A., 2013. Post-Variscan exhumation of the Central Anti-Atlas (Morocco) constrained by zircon and apatite fission-track thermochronology: Terra Nova, 25, 151-159.

Piqué, A., Tricart, P., Guiraud, R., Laville, E., Bouaziz, S., Amrhar M. and Ouali, R.A., 2002. The Mesozoic-Cenozoic Atlas belt (North Africa): an overview: Geodinamica Acta, $15,185-208$.

Press, W.H., Flannery, B.P., Teukolsky, S.A. and Vetterling, W.T., 1992. Numerical Recipes in FORTRAN 77: Volume 1, Fortran Numerical Recipes. Cambridge University Press.

Ranke, U., von Rad, U., \& Wissmann, G., 1982. Stratigraphy, facies and tectonic development of the on-and offshore Aaiun-Tarfaya Basin-A review. In: Geology of the Northwest African continental margin. Springer Berlin Heidelberg.

Rougier, S., Missenard, Y., Gautheron, C., Barbarand, J., Zeyen, H., Pinna, R., Liégeois, J.-P., Bonin, B., Ouabadi, A., El-Messaoud Derder, M., Frizon de Lamotte, D., 2013. Eocene exhumation of the Tuareg Shield (Sahara Desert, Africa): Geology, 41, 615-618.

Ruiz, G.M., Helg, U., Negro, F., Adatte, T. and Burkhard, M., 2008. Illite crystallinity patterns in the Anti-Atlas of Morocco: Swiss Journal of Geosciences, 101, 387-395.

Ruiz, G.M.H., Sebti, S., Negro, F., Saddiqi, O., Frizon de Lamotte, D., Stockli, D., Foeken, J., Stuart, F., Barbarand, J. and Schaer, J.P., 2011. From central Atlantic continental rift to Neogene uplift - western Anti-Atlas (Morocco): Terra Nova, 23, 35-41.

Saddiqi, O., Rjimati, E., Michard, A., Soulaimani, A. and Ouanaimi, H., 2015. Recommended Geoheritage Trails in Southern Morocco: A 3 Ga Record Between the Sahara Desert and the Atlantic Ocean. In: From Geoheritage to Geoparks, Geoheritage, Geoparks and Geotourism. Springer International Publishing.

Sahabi, M., Aslanian, D. and Olivet, J. L., 2004. A new starting point for the history of the central Atlantic: Comptes Rendus Geoscience, 336, 1041-1052. 
Sebti, S., 2011. Mouvements verticaux de l'Anti-Atlas occidental Marocain (Kerdous \& Ifni): Thermochronologie par traces de fission: PhD Thesis, Université Hassan II Casablanca, $173 \mathrm{pp}$.

Sebti, S., Saddiqi, O., Haimer, El, F.-Z., Michard, A., Ruiz, G., Bousquet, R., Baidder, L. and Frizon de Lamotte, D., 2009. Vertical movements at the fringe of the West African Craton: First zircon fission track datings from the Anti-Atlas Precambrian basement, Morocco: Comptes Rendus Geoscience, 341, 71-77.

Sehrt, M., Glasmacher, U. A., Stockli, D. F., Jabour, H., and Kluth, O., 2017. The southern Moroccan passive continental margin: An example of differentiated long-term landscape evolution in Gondwana: Gondwana Research, In Press.

Shuster, D.L., Flowers, R.M. and Farley, K.A., 2006. The influence of natural radiation damage on helium diffusion kinetics in apatite: Earth and Planetary Science Letters, 249, $148-161$.

Soulaimani, A., Michard, A., Ouanaimi, H., Baidder, L., Raddi, Y., Saddiqi, O. and Rjimati, E.C., 2014. Late Ediacaran-Cambrian structures and their reactivation during the Variscan and Alpine cycles in the Anti-Atlas (Morocco): Journal of African Earth Sciences, 98, 94112.

Tassone, D.R., Holford, S.P., Hillis, R.R. and Tuitt, A.K., 2012. Quantifying Neogene plate-boundary controlled uplift and deformation of the southern Australian margin: Geological Society, London, Special Publications, 367, 91-110.

Thomas, R.J., Fekkak, A., Ennih, N., Errami, E., Loughlin, S.C., Gresse, P.G., Chevallier, L.P. and Liégeois, J.P., 2004. A new lithostratigraphic framework for the Anti-Atlas Orogen, Morocco: Journal of African Earth Sciences, 39, 217-226.

Vermeesch, P., 2009. RadialPlotter: A Java application for fission track, luminescence and other radial plots: Radiation Measurements, 44, 409-410. 
Watts, A.B., 2012. Models for the evolution of passive margins. In: Regional Geology and Tectonics: Phanerozoic Rift Systems and Sedimentary Basins. Elsevier, Amsterdam.

Wildman, M., Brown, R., Watkins, R., Carter, A., Gleadow, A. and Summerfield, M., 2015. Post break-up tectonic inversion across the southwestern cape of South Africa: New insights from apatite and zircon fission track thermochronometry: Tectonophysics, 654, $30-55$.

Yamato, P., Husson, L., Becker, T.W. and Pedoja, K., 2013. Passive margins getting squeezed in the mantle convection vice: Tectonics, 32, 1559-1570.

Yazidi, A., Benziane, F., Hassenforder, B., Destombes, J., Hollard, H., Bourgin, R. and Oliva, P., 1991. Carte Géologique du Maroc: Tiznit, scale 1/100000: Notes et Mémoires du Service Géologique du Maroc, 360.

Yazidi, A., Benziane, F., Hollard, H., Oliva, P. and Destombes, J., 1986. Carte Géologique du Maroc and Notice: Sidi Ifni, scale 1/100000: Notes et Mémoires du Service Géologique du Maroc, 310. 


\section{Appendix}

The sediments exposed along Craima Beach were mapped by Yazidi et al. (1986) as Lower to Middle Cretaceous red sandstones with conglomerate interbeds, bituminous marls and limestones with Natica and Ampulina of Sidi Ouarzik, overlying red conglomerates. The age was originally established on poorly preserved ostracods.

A detailed study of the faunal content of the succession is in progress (Arantegui et al., in prep.). The micro- and macro-palaeontology analysis show that the assemblage of benthic foraminifera (fig. A) [Nautiloculina oolithica (Möhler)], green algae (fig. B) [Holosporella siamensis (Pia)], nerinids gastropods (fig. C) [Nerinella elegantula (d'Orbigny), Ampullospira actaea (d'Orbigny), and Ceritella dewalquei (Piette)] and trigoniids bivalves (fig. D) [Trigonia pullus (J. de C. Sowerby)] unequivocally indicates a Middle Jurassic age by comparison with the known occurrence of its components in western Europe (Fischer, 1969; Elliott, 1983; Bassoulet, 1987; Kuss, 1990; Fischer and Weber, 1997; Holzapfel, 1998).

In the north of the present study outcrops are mapped as Lower Cretaceous red conglomerates, sandstones and grey and pink argillaceous sandstones overlain by Middle Cretaceous dolomites, limestones and marly limestones with trigoniids, alectryonids and nerineids (Yazidi et al., 1991). The great resemblance in facies and fauna with the study area of Arantegui et al. (in prep.) strongly suggests a generalized misdating of the Mesozoic outcrops in the Sidi Ifni area. 

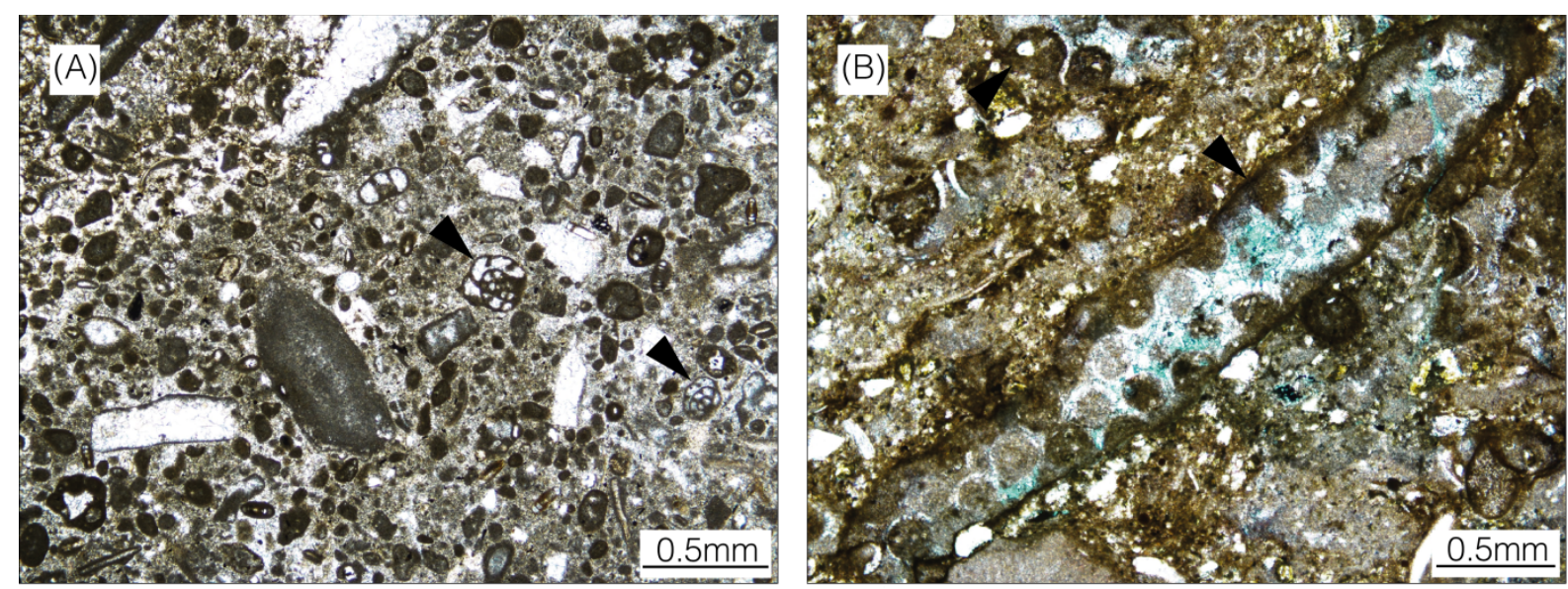

(C)

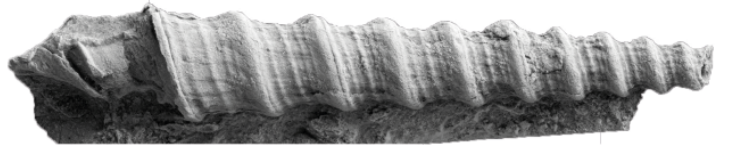

$\underline{5 \mathrm{~mm}}$

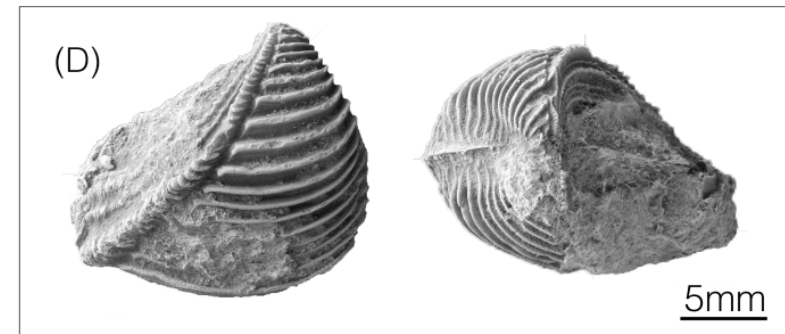

Micro- and macro-fauna from the Middle Jurassic assemblage in the limestones of Craima beach. A) Nautiloculina oolithica, B) Holosporella siamensis, C) Nerinella eleganta, and D) Trigonia pullus. 


\section{Appendix References}

Arantegui et al., in prep.. New data from the eastern margin of the Central Atlantic constraining early Mesozoic and post-rift evolution and depositional systems (provisional title). Now published: Arantegui, A., Jerrett, R., Schröder, S., Bulot, L.G., Gatto, R., Monari, S. and Redfern, J., 2019. Constraining Mesozoic early post-rift depositional systems evolution along the eastern Central Atlantic margin. Sedimentary Geology, 386, pp.31-51.

Fischer, J.-C., 1969. Géologie, paléontologie et paléoécologie du Bathonien en sud-ouest du Massiv Ardennais: Mémoires du Muséum National d'Histoire naturelle de Paris, 20, 319pp.

Fischer, J.-C. and Weber, C., 1997. Révision critique de la Paléontologie Française d'Al cide d'Orbigny (incluant la réédition de l'original). Volume II, gastropodes jurassiques: Muséum National d'Histoire Naturelle de Paris, 2, 300pp.

Holzapfel, S., 1998. Palökologie benthischer Faunengemeinschaften und Taxonomie der Bivalven im Jura von Südtunesien: Beringeria, 22, 3-119.

Yazidi, A., Benziane, F., Hassenforder, B., Destombes, J., Hollard, H., Bourgin, R. and Oliva, P., 1991. Carte Géologique du Maroc: Tiznit, scale 1/100000: Notes et Mémoires du Service Géologique du Maroc, 360, 1pp.

Yazidi, A., Benziane, F., Hollard, H., Oliva, P. and Destombes, J., 1986. Carte Géologique du Maroc and Notice: Sidi Ifni, scale 1/100000: Notes et Mémoires du Service Géologique du Maroc, 310, 1pp.

Bassoulet, J.-P. 1987. Sarfatiella dubari Conrad \& Peybernès 1973: a junior synonym of Holosporella siamensis Pia 1930 : 4th International Symposium on Fossil Algae, Friends of the Algae Newsletter, 20-21.

Elliott, G.F. 1983. Distribution and affinities of the Jurassic dasycladalean alga Sarfatiella: Palaeontology, 26, 671-675. 
Kuss, J. 1990. Middle Jurassic Calcareous Algae from the Circum-Arabian Area: Facies, 22, 59-85.

Kuznetsova, K.K., Grigelis, A., Adjamian, J. and Hallaq, L. 1996. Zonal stratigraphy and foraminifera of the Tethyan Jurassic (Eastern Mediterranean): Gordon and Breach Publishers, 256pp. 